\title{
Validation of reference genes for expression analysis in the salivary gland and the intestine of Rhodnius prolixus (Hemiptera, Reduviidae) under different experimental conditions by quantitative real-time PCR
}

\author{
Rafaela M Paim¹, Marcos H Pereira 1,3, Raffaello Di Ponzio ${ }^{1}$, Juliana O Rodrigues², Alessandra A Guarneri ${ }^{2,3}$, \\ Nelder F Gontijo ${ }^{1,3}$ and Ricardo N Araújo ${ }^{1,3^{*}}$
}

\begin{abstract}
Background: Rhodnius prolixus is a blood-feeding insect that can transmit Trypanosoma cruzi and Trypanosoma rangeli to vertebrate hosts. Recently, genomic resources for invertebrate vectors of human pathogens have increased significantly, and $R$. prolixus has been one of the main species studied among the triatomines. However, the paucity of information on many of the fundamental molecular aspects of this species limits the use of the available genomic information. The present study aimed to facilitate gene expression studies by identifying the most suitable reference genes for the normalization of mRNA expression data from qPCR.

Results: The expression stability of five candidate reference genes (18S rRNA, GAPDH, $\beta$-actin, $\alpha$-tubulin and ribosomal protein L26) was evaluated by QPCR in two tissues (salivary gland and intestine) and under different physiological conditions: before and after blood feeding and after infection with $T$. cruzi or T. rangeli. The results were analyzed with three software programs: geNorm, NormFinder and BestKeeper. All of the evaluated candidate genes proved to be acceptable as reference genes, but some were found to be more appropriate depending on the experimental conditions. 18S, GAPDH and $\alpha$-tubulin showed acceptable stability for studies in all of the tissues and experimental conditions evaluated. $\beta$-actin, one of the most widely used reference genes, was confirmed to be one of the most suitable reference genes in studies with salivary glands, but it had the lowest expression stability in the intestine after insect blood feeding. L26 was identified as the poorest reference gene in the studies performed.

Conclusions: The expression stability of the genes varies in different tissue samples and under different experimental conditions. The results provided by three statistical packages emphasize the suitability of all five of the tested reference genes in both the crop and the salivary glands with a few exceptions. The results emphasise the importance of validating reference genes for qRT-PCR analysis in $R$. prolixus studies.
\end{abstract}

\section{Background}

Triatomines (Hemiptera, Reduviidae) are hematophagous insects and the vectors of Trypanosoma cruzi, the causative agent of Chagas disease in the Americas. For successful transmission, the parasite undergoes different

\footnotetext{
* Correspondence: rnaraujo@icb.ufmg.br

'Departamento de Parasitologia, Instituto de Ciências Biológicas, Universidade Federal de Minas Gerais. Bloco 14, Sala 177, Av. Antonio Carlos 6627, Pampulha, CEP 30270-901 Belo Horizonte, MG, Brazil

Full list of author information is available at the end of the article
}

stages of transformation in the gut of the insect vector until it is eliminated with the feces and urine [1]. Bugs from the genus Rhodnius can also be infected and transmit the protozoan Trypanosoma rangeli, which despite being non-pathogenic to humans and animals, can cause physiological damage to the insect vector $[2,3]$. Unlike T. cruzi, which develops exclusively in the gut of its invertebrate hosts, $T$. rangeli initially develops in the gut and then invades the hemolymph of the insect vector. 
The protozoan is transmitted to the vertebrate host through salivary secretion during feeding $[2,4]$.

All nymphal and adult stages of triatomines feed exclusively on blood. The salivary glands and the intestine are the major organs involved in the interaction of the triatomine with trypanosomatids, and its vertebrate hosts and play a critical role in parasite development and blood intake during hematophagy [5-8].

In the last few years, the genomic resources for the invertebrate vectors of human pathogens have increased significantly [9]. Among the invertebrate vectors, the triatomine bug Rhodnius prolixus, the main vector of T. cruzi in the northern region of South America [10], has been studied. Sequences from Rhodnius prolixus are available to the scientific community, including more than 28,000 nucleotide sequences from transcriptomes and other studies $[11,12]$ and more than 5 million contigs from the Rhodnius prolixus genome project (http:// genome.wustl.edu/genomes/view/rhodnius_prolixus/). With the completion of the genome project, it is expected that the number of studies involving gene expression will increase.

Understanding the patterns of gene expression is important to provide insights into complex regulatory networks and will lead to the identification of genes relevant to new biological processes [13]. However, gene expression studies need robust normalization methods, which are necessary for the correction of non-specific variations, such as different amounts of starting material, inaccurate quantification of RNA, the quality of the RNA, and differences during cDNA synthesis that can trigger variations in PCR reactions. The most common method for normalizing gene expression levels is to normalize the mRNA levels of the gene of interest to endogenous control genes, often referred to as housekeeping or reference genes. Ideally, the housekeeping gene should not be regulated or influenced by the experimental procedure or co-regulated with the target gene. The housekeeping gene should also be expressed in abundance and have minimal innate variability [14].

Studies with triatomines and other insect models have shown that the expression levels of commonly used reference genes can differ among different tissue/organ types or physiological conditions [15-18]. In the present study, the expression level and stability of five potential reference genes were compared in two different tissues, the salivary glands and the crop (anterior midgut), from Rhodnius prolixus nymphs under two different physiological conditions: after blood feeding and after infection with trypanosomatids (T. rangeli and T. cruzi). The results from this study will help in choosing suitable genes for the normalization of mRNA under conditions that are the focus of most studies on triatomines, such as before and after hematophagy and during the triatomine-trypanosomatid interaction.

\section{Methods}

\section{Insects and parasites}

$R$. prolixus were reared under controlled conditions of temperature $\left(28 \pm 2^{\circ} \mathrm{C}\right)$ and humidity $(65 \pm 5.0 \%)$ in a $12 / 12 \mathrm{~h}$ light/dark cycle and allowed to feed weekly on chickens or rats. Cultured epimastigotes from T. rangeli (CHOACHI strain) and T. cruzi (CL strain) were used. The epimastigote forms were cultured at $27^{\circ} \mathrm{C}$ in liverinfusion tryptose (LIT) medium supplemented with $15 \%$ fetal bovine serum, $100 \mathrm{mg} / \mathrm{ml}$ streptomycin and 100 units $/ \mathrm{ml}$ penicillin. To maintain the infectivity, a cyclic infection of triatomines and mice with each parasite was performed every three months. Infection and bloodfeeding experiments followed the UFMG and FIOCRUZ guidelines on animal experimentation and were approved by the Ethical Committee on Animal Use (CEUA- FIOCRUZ-MG) under the number L-058/08.

\section{Blood feeding on rats}

The salivary glands and the crop of third instar nymphs of $R$. prolixus were dissected at different starving times after molt (1, 3, 15 and 25 days) or different times after blood feeding (1, 3 and 7 days) on anesthetized rats. Samples were immediately frozen at $-80^{\circ} \mathrm{C}$ until RNA extraction.

\section{Infection with $T$. rangeli and $T$. cruzi}

For $T$. rangeli salivary gland infection, fourth instar nymphs were infected intracoelomically with $1 \mu$ of PBS containing 100 parasites, and a control group was inoculated with PBS alone. The epimastigotes were obtained from 10-day-old culture medium, washed and resuspended in sterile PBS $(0.15 \mathrm{M} \mathrm{NaCl}$ in $0.01 \mathrm{M}$ sodium phosphate, $\mathrm{pH}$ 7.4). After 20 days of infection, the salivary glands of these insects were extracted and used in the experiments. Samples were immediately frozen at $-80^{\circ} \mathrm{C}$ until RNA extraction.

For intestinal infection with $T$. rangeli or $T$. cruzi, the epimastigotes were obtained as above but were added to heat-inactivated rabbit blood at a concentration of $10^{5}$ flagellates $/ \mathrm{ml}$. Second instar nymphs were allowed to feed on this blood through a membrane feeder (control insects were fed on non-infected blood). Fifteen days after the molt to the third instar, the insects in the chronic phase of infection had their crop extracted for experiments. Samples were immediately frozen at $-80^{\circ} \mathrm{C}$ until RNA extraction.

\section{Selection of gene sequences and primer design}

Five genes were selected for analysis: $\beta$-actin $(A C T$, GenBank ID: EU233794), $\alpha$-tubulin (TUB, GenBank ID: $\mathrm{ACPB} 02030650)$, the $60 \mathrm{~S}$ subunit of a ribosomal protein L16 (L26, GenBank ID: ACPB02039040), glyceraldehyde3-phosphate dehydrogenase (GAPDH, GenBank ID: 
ACPB02038754) and $18 S$ ribosomal RNA (18S, GenBank ID: AJ421962) (Table 1).

The sequences were obtained from the contigs from the genome project (http://genome.wustl.edu/pub/ organism/Invertebrates/Rhodnius_prolixus/assembly/ Rhodnius_proli xus-3.0.1/output/). The primers used in the PCR reactions were designed with Primer3 software (http://primer3.sourceforge.net) using a maximum amplified fragment of $150 \mathrm{bp}$ and a melting temperature (Tm) of approximately $60^{\circ} \mathrm{C}$ (Table 1 ).

\section{Total RNA isolation, cDNA synthesis and PCR}

Total RNA was extracted from three pools of 10 crops or three pools of 20 salivary glands from each group with the Nucleospin ${ }^{\circledR}$ RNA XS (Macherey-Nagel) according to the manufacturer's instructions. DNAse treatment was performed on column according to the Nucleospin ${ }^{\circledR}$ RNA XS (Macherey-Nagel) manufacturer's instructions. The RNA was quantified using a NanoDrop ${ }^{\circledR}$ ND-1000 (Thermo Scientific) at $260 \mathrm{~nm}$. Only intact RNA was used for the reactions. RNA should have the ratio 260/280 (absorbance at 260/absorbance at 280) between 1.8 and 2.0, and the subunits of $28 \mathrm{~S}$ and $18 \mathrm{~S}$ clearly observed by native agarose gel electrophoresis. RNA $(0.5 \mu \mathrm{g})$ was used for cDNA synthesis with $0.5 \mu \mathrm{g}$ of random hexamers (Promega) using the M-MLV reverse transcriptase system (Promega) in a final volume of $25 \mu \mathrm{l}$. The product was used as a template for PCR reactions of housekeeping genes, which were performed for 35 cycles $\left(94^{\circ} \mathrm{C}\right.$ for $30 \mathrm{~s}, 60^{\circ} \mathrm{C}$ for $30 \mathrm{~s}$ and $72^{\circ} \mathrm{C}$ for $45 \mathrm{~s}$ ) with $1 \mu \mathrm{l}$ of cDNA, $200 \mathrm{nM}$ of each primer, $200 \mu \mathrm{M}$ of dNTPs and $1 \mathrm{U}$ of Taq polymerase (Phoneutria) in a final volume of $20 \mu \mathrm{l}$.

\section{Cloning and sequencing of DNA}

The PCR products were cloned into the pGEM-T Easy vector (Promega). After transformation into DH5 $\alpha$ competent cells, recombinant plasmid DNA was isolated using the Wizard Plus SV Miniprep kit (Promega). The
DNA inserts of the recombinant clones were amplified by PCR with universal primers - an M13 forward primer and an M13 reverse primer - derived from the vector. The sequencing reactions were conducted using the dideoxy method [19], and the samples were run on a MegaBACE 1000TM sequencing system (Amersham Biosciences). Each clone was sequenced twice in both directions, and the consensus sequence was derived from these sequences using the programs Phred v.0.20425 [20,21], Phrap v.0.990319 (http://www.phrap. org/), and Consed 12.0 [22]. The nucleotide sequences were compared with the GenBank nonredundant database using the basic local alignment search tool (BLAST 2.0) [23] from the National Center for Biotechnology Information (http://www.ncbi.nlm.nih.gov/blast/) and were compared to the $R$. prolixus genomic database.

\section{Real-time quantitative polymerase chain reaction (qPCR)}

The reactions were conducted using an ABIPRISM 7500 Sequence Detection System (Applied Biosystems). Each reaction was run in triplicate and contained $2 \mu \mathrm{l}$ of diluted cDNA (corresponding to $0.1 \mathrm{ng}$ of the starting amount of RNA for $18 \mathrm{~S}$ rRNA and $10 \mathrm{ng}$ for the other genes), $300 \mathrm{nM}$ of each primer and $12.5 \mu \mathrm{l}$ of Power $\mathrm{SYBR}^{\circledR}$ Green PCR Master Mix (Applied Biosystems) in a final volume of $25 \mu \mathrm{l}$. The cDNA was amplified at $95^{\circ} \mathrm{C}$ for $10 \mathrm{~min}$ followed by 40 cycles of $95^{\circ} \mathrm{C}$ for $15 \mathrm{~s}$ and $60^{\circ} \mathrm{C}$ for $1 \mathrm{~min}$. A reverse transcription negative control (without reverse transcriptase) and a non template negative control were included for each primer set to confirm the absence of genomic DNA and to check for primer-dimer or contamination in the reactions, respectively. To ensure that only a single product was amplified, a melting curve analysis was performed. The real-time PCR efficiency was determined for each gene using the slope of a linear regression model [24], which was determined by measuring the $\mathrm{C}_{\mathrm{T}}$ for a specific threshold for a range of serial dilutions, including 100 ,

Table 1 Description, primer sequence and amplicon characteristics for the five candidate reference genes tested

\begin{tabular}{|c|c|c|c|c|c|c|}
\hline Symbol & Name & Function & Primer Sequences & $\begin{array}{l}\text { Amplicon } \\
\text { size (bp) }\end{array}$ & $E(\%) *$ & $\mathbf{R}^{2 * *}$ \\
\hline$\overline{A C T}$ & $\beta$-actin & $\begin{array}{l}\text { Involved in cell } \\
\text { motility, structure and } \\
\text { integrity }\end{array}$ & $\begin{array}{l}\text { For 5' AATCAAGATCATTGCTCCACCAG 3' Rev 5' } \\
\text { TTAGAAGCATITGCGGTGGAC 3' }\end{array}$ & 151 & $92 \%$ & 0.996 \\
\hline GAPDH & $\begin{array}{l}\text { Glyceralde hyde-3- phosphate } \\
\text { dehydrogen ase }\end{array}$ & Glycolysis & $\begin{array}{l}\text { For 5' GATGGCGCCCAGTACATAGT 3' } \\
\text { Rev 5' AGCTGACGGGGCTGTTATTA 3' }\end{array}$ & 111 & $96 \%$ & 0.9906 \\
\hline TUB & $\alpha$-tubulin & $\begin{array}{l}\text { Cytoskeleton } \\
\text { structural protein }\end{array}$ & $\begin{array}{l}\text { For 5' TाTCCTCGATCACTGCTTCC 3' } \\
\text { Rev } 5^{\prime} \text { CGGAAATAACTGGGGCATAA 3' }\end{array}$ & 129 & $90.1 \%$ & 0.9978 \\
\hline$L 26$ & 605 ribosomal protein & $\begin{array}{l}\text { Structural constituent } \\
\text { of ribosome }\end{array}$ & $\begin{array}{l}\text { For 5' AGGTGGACAAAGATCGCAAG 3' } \\
\text { Rev 5' AAGTGTCCATTGCTGTCGTG 3' }\end{array}$ & 117 & $93 \%$ & 0.9991 \\
\hline 185 & $18 \mathrm{~S}$ ribosomal RNA & $\begin{array}{l}\text { Cytosolic small } \\
\text { ribosomal subunit }\end{array}$ & $\begin{array}{l}\text { For 5' TCCTTCGTGCTAGGAATTGG 3' } \\
\text { Rev 5' GTACAAAGGGCAGGGACGTA 3' }\end{array}$ & 105 & $100 \%$ & 0.9617 \\
\hline
\end{tabular}

*Real-time qPCR efficiency (calculated by the standard curve method)

** Regression coefficient calculated from the regression line of the standard curve 
$10,1,0.1$ and $0.01 \mathrm{ng}$ of cDNA. The corresponding realtime PCR efficiencies were calculated according to Radonic et al. [14].

\section{Statistical analysis}

Raw $C_{\mathrm{T}}$ values were first analyzed by the KolmogorovSmirnov test to check for normality. The non-parametric Mann-Whitney test was applied using the GraphPad Prism ${ }^{\circledR} 5.0$ considering probabilities of $\mathrm{P}<0.01$ as significant [25]. Quantitative expression measurements of all of the candidate genes tested across different tissues and conditions obtained by qPCR were analyzed by the three statistical algorithms most commonly used for assessing the appropriateness of reference genes: geNorm [13], NormFinder [26] and BestKeeper [27], which are all freely available for download from the authors' websites.

\section{Results}

Target amplification efficiencies and expression levels of the candidate reference genes

The initial screening of five potential reference genes by PCR showed that all of the genes were expressed in $R$. prolixus salivary glands and crop, indicated by the presence of a single amplicon of the expected size on a $2 \%$ agarose gel. All of the amplicons were sequenced and displayed $>98 \%$ identity with the sequences from which the primer design was based. The efficiencies of the qPCR reactions were calculated from the formula $\mathrm{E}=10^{1 / \text {-slope }}$ - 1 and varied from $90.1 \%$ for TUB to $100 \%$ for $18 S$; the regression coefficients ranged from 0.9617 to 0.9991 for $18 S$ and $L 26$, respectively (Table 1 ).

The analysis of the raw expression levels identified variation among the reference genes (Figure 1). The $\mathrm{C}_{\mathrm{T}}$ values for the mRNAs selected as the candidate reference genes (Additional file 1) ranged from 11.31 (18S) to 25.42 (L26), and these two transcripts showed the most and the least abundant expression levels, respectively, in both tissue types tested (Figure 1a and $1 b)$. The average $C_{T}$ values obtained for all of the genes studied did not show significant differences between the crop and the salivary gland, but the range of values was consistently narrower in the crop than in the salivary glands, except for the $A C T$ gene (Figure 1a and $1 \mathrm{~b})$. qPCR amplification of $18 \mathrm{~S}$, which is generally highly expressed in triatomine cells, produced $\mathrm{C}_{\mathrm{T}}$ values much lower than the other transcripts in all of the samples $\left(C_{T}\right.$ mean $\left.=12.07\right)$ despite the additional 1:100 dilution of the cDNA template. The other candidate reference genes were expressed at moderate levels, with mean $C_{\mathrm{T}}(\mathrm{n}=37$ samples $)$ values of $17.93,18.69$, 23.49, and 20.82, respectively, for ACT, TUB, L26 and GAPDH (Figure 1c).

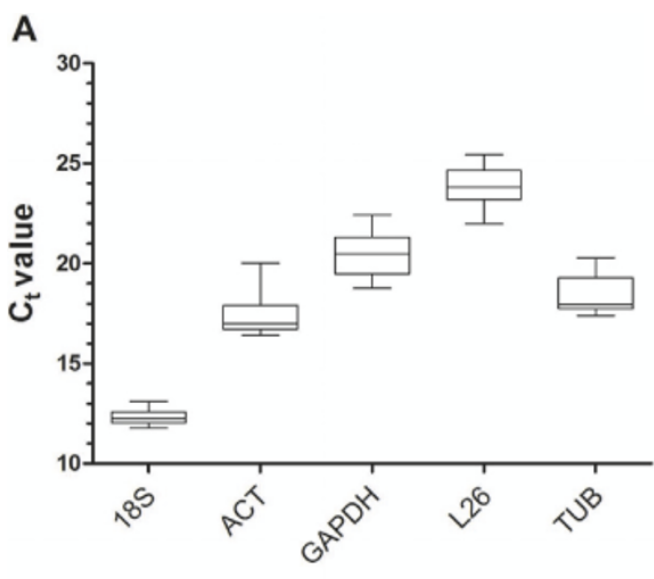

B
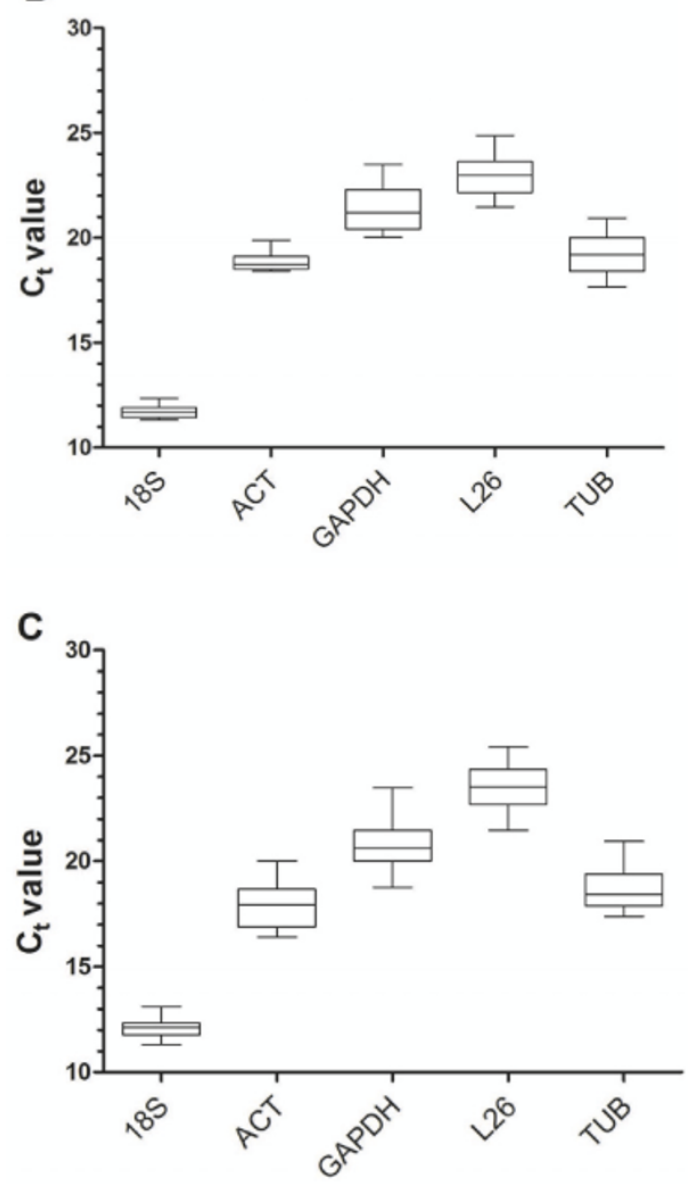

Figure 1 The variation in gene expression in the tissues as indicated by the raw $C_{T}$ values. The box plots show the expression levels of the candidate reference genes in (A) all of the crop samples $(n=22)$, (B) all of the salivary glands samples $(n=15)$ and $(C)$ all of the tissues and conditions $(n=37)$. The values are given as the cycle threshold $\left(C_{T}\right.$, mean of triplicate samples). The global expression levels of the different genes analyzed are shown as the 25th and 75th quartiles (horizontal lines), median (emphasized horizontal line) and minimal to maximal value (whiskers) 


\section{Gene expression stability of the candidate reference genes}

Ct values obtained in each situation showed that the variation of the gene expression was not significant ( $p>$ 0.01 ) in any organ and treatment (Table 2). Therefore, all of them were used for the analysis to identify the best reference genes.

\section{geNorm analysis}

The geNorm program was used to identify genes that were the most stably expressed in different tissues or physiological conditions. The program defines two parameters to quantify the housekeeping gene stability: $M$ (the average expression stability) and V (the pairwise variation). The gene with the lowest $M$ value is considered to have the most stable expression, while the one with the highest $M$ value has the least stable expression. All analyzed genes reached high expression stability with M-values below 0.5, except for L26 and GAPDH that showed M-values between 0.5 and 1.0 in three and one situation, respectively (Figure 2).

The gene that coded for $\alpha$-tubulin proved to be one of the most stable genes in both tissues (salivary gland and crop) under the three experimental conditions (blood feeding, $T$. rangeli infection and $T$. cruzi infection). $18 S$ was also among the three most stable genes in all of the conditions. ACT expression was variable under blood feeding conditions, but showed highly stable expression in the salivary glands. However, $A C T$ was the most unstable in the crop of the same insects. L26 was the least (or one of the least) stable genes in all of the tissues and evaluated conditions.

For all of the conditions (independent of the tissue or condition evaluated), combining the two most stably expressed genes produced optimal normalization. Indeed, inclusion of a third reference gene did not significantly contribute to the variation of the normalization factor because the $V 2 / 3$ value (the pairwise variation when the number of normalization factors is increased from two to three) was below the default cut-off value of $\mathrm{V}=0.15$ [13] (Figure 3).

\section{BestKeeper analysis}

According to the BestKeeper (Table 3) analysis, the candidate reference genes were stable in all of the tissues and experimental conditions because none showed SD values higher than 1 . The single exception was the expression of L26 in the salivary glands after blood feeding, which presented the highest overall variation with an $\mathrm{SD}\left[ \pm \mathrm{C}_{\mathrm{T}}\right]>1$ and an SD $[ \pm \mathrm{x}$-fold $]>2$, which makes its use as a reference gene unacceptable in that experimental condition. 18S, TUB and $A C T$ were among the three most stable genes in almost all of the conditions; these genes only varied in the rank position. Despite being at acceptable levels, $A C T$ had the highest variation in the crop under blood feeding conditions. L26 and GAPDH exhibited the highest standard deviation in most of the conditions evaluated, indicating that these were the least stable reference genes.

\section{NormFinder analysis}

According to the NormFinder, the genes that are more stably expressed are indicated by lower average expression stability values. In contrast with the other two software analyses, the NormFinder algorithm identified GAPDH as one of the three most stable genes in almost all of the tissues and conditions, instead of $18 \mathrm{~S}$, which often appeared in one of the top three positions in the other rankings (Table 4). An exception was the expression of GAPDH in the $R$. prolixus crop after $T$. rangeli infection in which $G A P D H$ was the most unstable gene. TUB and $A C T$ were among the three most stable genes in nearly all of the tissues and conditions, in agreement with the other two programs. The exception was the expression of $A C T$ in the crop after blood feeding, which together with $L 26$, was the least stable gene in this condition.

The NormFinder algorithm also ranked the various candidate reference genes according to their intragroup expression variation. The comparisons were performed with organs and treatments that had subgroups, such as the salivary glands and crop with different times during starvation (subgroups: 1, 3, 15 and 25 days of starvation) and with different times after blood feeding (subgroups:

Table $2 \mathrm{P}$ values calculated by the two tailed Mann-Whitney test with the raw $\mathrm{C}_{\mathrm{T}}$ values of the genes in the salivary gland and crop after bloodfeeding* or infection** with T.cruzi or T. rangeli

\begin{tabular}{|c|c|c|c|c|c|}
\hline & \multicolumn{2}{|c|}{ Salivary Gland } & \multicolumn{3}{|c|}{ Crop } \\
\hline & Blood feeding & T. rangeli infection & Blood feeding & T. rangeli infection & T. cruzi infection \\
\hline GAPDH & 1.000 & 0.036 & 0.057 & 0.071 & 1.000 \\
\hline TUB & 0.857 & 0.036 & 0.629 & 0.051 & 0.686 \\
\hline L26 & 0.628 & 0.571 & 0.114 & 0.393 & 0.200 \\
\hline $\mathrm{ACT}$ & 0.400 & 1.000 & 0.226 & 0.250 & 0.245 \\
\hline $18 S$ & 0.400 & 0.714 & 0.226 & 0.571 & 0.886 \\
\hline
\end{tabular}

* Comparison between before and after bloodfeeding

${ }^{*}$ Comparison between infected and non-infected 


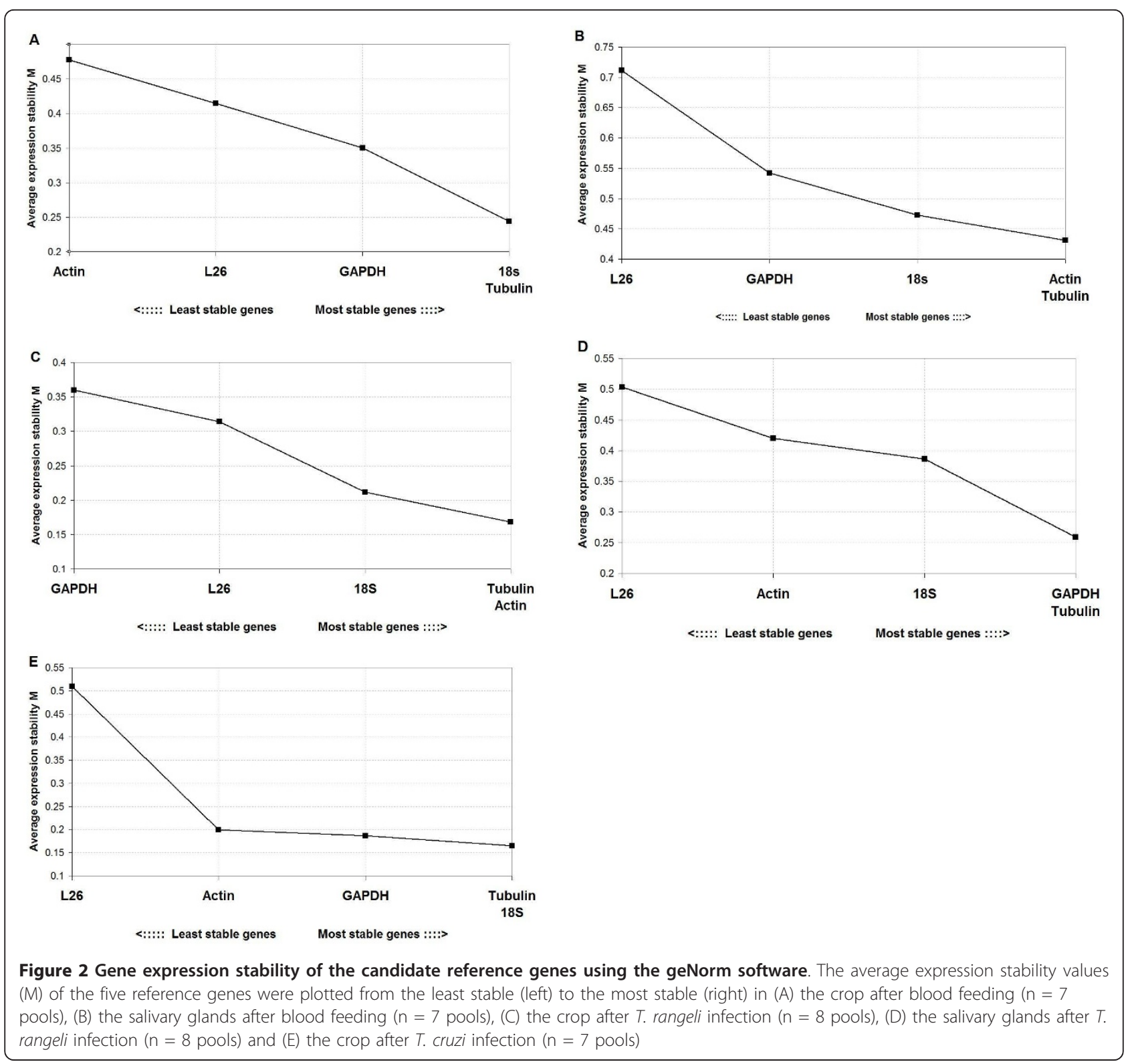

1, 3 and 7 days after feeding) (Table 5). In the salivary glands, L26 was the most variable gene (with the highest stability value) in both starving and feeding groups, while in the crop, it was only the most variable gene in starving insects. When the crop was compared at timepoints after blood feeding, the most variable gene was $A C T$. This result reinforces the unacceptable use of $A C T$ as a reference gene in this condition.

\section{Discussion}

qPCR has become the most important method for the quantification of mRNA transcription levels due to its outstanding accuracy, broad dynamic range, and sensitivity. Normalization is a very important preliminary phase in the study of gene expression and requires the selection of a reference control, the expression of which may be influenced by experimental treatments in different tissues, which could lead to a misinterpretation of the results [28]. In triatomines, a variety of housekeeping genes has been frequently used in gene expression analysis. Among them, the most commonly used are $18 \mathrm{~S}$ rRNA $[5,6,29,30]$ and $\beta$-actin [31-35]. Other genes, including the gene that codes for the protein UGALT, have also been suggested as housekeeping genes [11]. Although UGALT has been shown to be stable in groups with similar physiological status [36], its mRNA levels varied in nymphs at different days after feeding (data not shown). Recently, Majerowicz et al. evaluated seven 


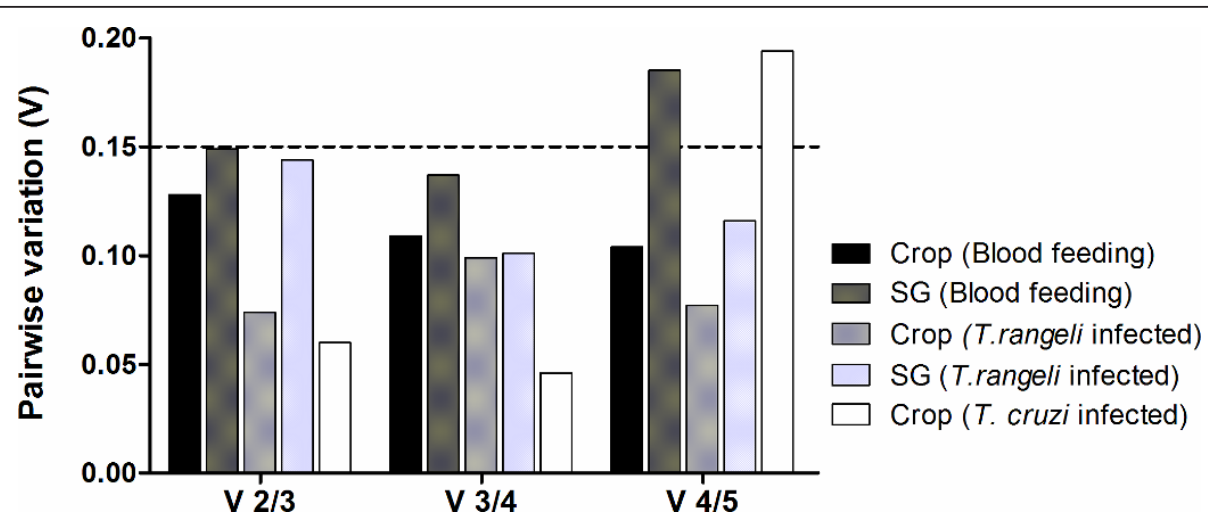

Figure 3 The pairwise variation (V) of the candidate reference genes for accurate normalization in the two tissue samples in the different conditions: after blood feeding, $\boldsymbol{T}$. rangeli infection or $\boldsymbol{T}$. cruzi infection. The threshold value (0.15) is marked with a dashed line and indicates that the use of only the two most stable genes was sufficient to obtain an accurate normalization in all of the analyzed groups ( $V$ $2 / 3<0.15)$. SG, salivary gland.

Table 3 Descriptive statistics of the five candidate reference genes based on their cyclethreshold value $\left(C_{T}\right)$ as calculated by the BestKeeper algorithm

\begin{tabular}{|c|c|c|c|c|c|c|c|}
\hline & & Ranking $\rightarrow$ & 1 & 2 & 3 & 4 & 5 \\
\hline \multirow[t]{15}{*}{ R. prolixus crop } & & Gene name & 185 & $T U B$ & $L 26$ & GAPDH & $A C T$ \\
\hline & Samples after blood feeding & Geo mean $\left(C_{T}\right)$ & 12.66 & 19.45 & 24.38 & 21.68 & 18.28 \\
\hline & & $\operatorname{Min}-\max \left(C_{T}\right)$ & $12.25-13.10$ & 19.18-20.27 & 23.51-24.86 & 21.23-22.43 & 18.88-20.0 \\
\hline & & Std dev $\left( \pm C_{T}\right)$ & 0.17 & 0.23 & 0.41 & 0.43 & 0.52 \\
\hline & & Std dev ( $\pm x$-fold $)$ & 1.12 & 1.18 & 1.33 & 1.35 & 1.43 \\
\hline & Samples after T. rangeli infection & Gene name & $A C T$ & $T U B$ & 185 & $L 26$ & GAPDH \\
\hline & & Geo mean $\left(C_{T}\right)$ & 16.93 & 17.70 & 12.06 & 23.73 & 20.53 \\
\hline & & Min-max $\left(C_{T}\right)$ & 16.64-17.11 & $17.38-18.14$ & $11.78-12.48$ & $23.1-24.67$ & 19.88-21.24 \\
\hline & & Std dev $\left( \pm C_{T}\right)$ & 0.12 & 0.15 & 0.17 & 0.40 & 0.41 \\
\hline & & Std dev ( $\pm x$-fold $)$ & 1.09 & 1.11 & 1.12 & 1.32 & 1.33 \\
\hline & Samples after T. cruzi infection & Gene name & 185 & $T U B$ & $A C T$ & GAPDH & $L 26$ \\
\hline & & Geo mean $\left(C_{T}\right)$ & 12.21 & 18.02 & 16.66 & 19.22 & 23.33 \\
\hline & & Min-max $\left(C_{T}\right)$ & $11.91-12.44$ & $17.86-18.35$ & $16.39-17.30$ & $18.76-19.72$ & $21.99-25.42$ \\
\hline & & Std dev $\left( \pm C_{T}\right)$ & 0.09 & 0.17 & 0.25 & 0.26 & 0.93 \\
\hline & & Std dev ( $\pm x$-fold $)$ & 1.07 & 1.13 & 1.19 & 1.20 & 1.90 \\
\hline \multicolumn{8}{|l|}{ R. prolixus } \\
\hline \multirow[t]{10}{*}{$\underline{\text { Salivary glands }}$} & Samples after blood feeding & Gene name & $18 S$ & $A C T$ & TUB & GAPDH & $L 26$ \\
\hline & & Geo mean $\left(C_{T}\right)$ & 12.03 & 19.09 & 20.00 & 22.18 & 23.05 \\
\hline & & $\operatorname{Min}-\max \left(C_{T}\right)$ & $11.75-12.34$ & 18.49-19.89 & 19.19-20.94 & $21.21-23.48$ & $21.00-24.87$ \\
\hline & & Std dev $\left( \pm C_{T}\right)$ & 0.23 & 0.46 & 0.47 & 0.65 & 1.17 \\
\hline & & Std dev ( $\pm x$-fold $)$ & 1.17 & 1.38 & 1.39 & 1.56 & 2.24 \\
\hline & Samples after T. rangeli infection & Gene name & 185 & $A C T$ & GAPDH & TUB & $L 26$ \\
\hline & & Geo mean $\left(C_{T}\right)$ & 11.47 & 18.68 & 20.52 & 18.45 & 22.94 \\
\hline & & $\operatorname{Min}-\max \left(C_{T}\right)$ & $11.31-11.69$ & $18.42-18.97$ & $20.02-21.53$ & 17.64-19.33 & $21.47-23.65$ \\
\hline & & Std dev $\left( \pm C_{T}\right)$ & 0.11 & 0.19 & 0.26 & 0.39 & 0.49 \\
\hline & & Std dev ( $\pm x$-fold $)$ & 1.08 & 1.14 & 1.20 & 1.31 & 1.41 \\
\hline
\end{tabular}

$\left[C_{T}\right]$, cycle threshold; Geo Mean $\left[C_{T}\right]$, geometric mean $\left[C_{T}\right] ;$ Min-max $\left[C_{T}\right]$, extreme values of $C_{T} ; \operatorname{Std} \operatorname{dev}\left[ \pm C_{T}\right]$, standard deviation $\left[ \pm C_{T}\right] ;$ Std dev $[ \pm x$-fold], standard deviation of the absolute regulation coefficients 
Table 4 Expression stability values from the candidate reference genes calculated by the NormFinder software

\begin{tabular}{|c|c|c|c|c|c|c|c|c|c|}
\hline \multicolumn{4}{|c|}{ R. prolixus salivary glands } & \multicolumn{6}{|c|}{ R. prolixus crop } \\
\hline \multicolumn{2}{|c|}{ After blood feeding } & \multicolumn{2}{|c|}{ After $T$. rangeli infection } & \multicolumn{2}{|c|}{ After blood feeding } & \multicolumn{2}{|c|}{ After $T$. rangeli infection } & \multicolumn{2}{|c|}{ After $T$. cruzi infection } \\
\hline Ranking & $\begin{array}{l}\text { Stability } \\
\text { value* }\end{array}$ & Ranking & $\begin{array}{l}\text { Stability } \\
\text { value }\end{array}$ & Ranking & $\begin{array}{l}\text { Stability } \\
\text { value }\end{array}$ & Ranking & $\begin{array}{l}\text { Stability } \\
\text { value }\end{array}$ & Ranking & $\begin{array}{c}\text { Stability } \\
\text { value }\end{array}$ \\
\hline ACT & 0.118 & GAPDH & 0.152 & TUB & 0.039 & $T U B$ & 0.045 & ACT & 0.054 \\
\hline GAPDH & 0.125 & $T U B$ & 0.176 & GAPDH & 0.072 & ACT & 0.109 & GAPDH & 0.127 \\
\hline$T U B$ & 0.144 & $A C T$ & 0.181 & 185 & 0.078 & L26 & 0.172 & $T U B$ & 0.130 \\
\hline 185 & 0.185 & 185 & 0.202 & L26 & 0.168 & 185 & 0.174 & 185 & 0.188 \\
\hline L26 & 0.350 & L26 & 0.224 & ACT & 0.168 & GAPDH & 0.215 & L26 & 0.377 \\
\hline $\begin{array}{c}\text { Best } \\
\text { combination }\end{array}$ & $\begin{array}{l}\text { Stability } \\
\text { value }\end{array}$ & $\begin{array}{c}\text { Best } \\
\text { combination }\end{array}$ & $\begin{array}{l}\text { Stability } \\
\text { value }\end{array}$ & $\begin{array}{c}\text { Best } \\
\text { combination }\end{array}$ & $\begin{array}{l}\text { Stability } \\
\text { value }\end{array}$ & $\begin{array}{c}\text { Best } \\
\text { combination }\end{array}$ & $\begin{array}{l}\text { Stability } \\
\text { value }\end{array}$ & $\begin{array}{c}\text { Best } \\
\text { combination }\end{array}$ & $\begin{array}{l}\text { Stability } \\
\text { value }\end{array}$ \\
\hline $\begin{array}{c}\text { GAPDH and } \\
A C T\end{array}$ & 0.087 & TUB and $A C T$ & 0.077 & $\begin{array}{c}\text { GAPDH and } \\
\text { TUB }\end{array}$ & 0.043 & $T U B$ and $A C T$ & 0.074 & $\begin{array}{c}\text { GAPDH and } \\
A C T\end{array}$ & 0.077 \\
\hline
\end{tabular}

*The stability values are listed from the most stable to the least stable gene

genes in different organs of $R$. prolixus and identified that the best reference gene varied according to the tissue and physiological condition. Elongation factor 1 was the best in the posterior midgut, $\beta$-actin in the ovaries, $18 \mathrm{~s}$ ribosomal RNA in the fat body and embrionic lethal, abnormal vision in the posterior midgut infected with $T$. cruzi [18].

Rhodnius prolixus is currently being studied in several scientific projects, and the number of studies on $R$. prolixus is increasing due to the completion of the sequencing of its genome and the availability of an increasing number of transcribed sequences. Much attention is been given to organs related to the hematophagic process (such as the intestine and salivary glands), once they are important for the interaction between the vector and the host and are involved in the development and transmission of pathogens. The genes evaluated in the present study were selected based on their traditional use as internal controls in expression studies with triatomines (ACT and 18S) and other organisms (GAPDH, ribosomal proteins and tubulin) [17], and also by their availability in the $R$. prolixus Genbank. We also attempted to test other reference genes that are widely used in several

Table 5 Intra-group variation represented by the stability values calculated by the NormFinder software in the salivary glands and the crop of starving and blood-fed insects.

\begin{tabular}{ccccc}
\hline Tissue & \multicolumn{2}{c}{ Salivary Glands } & \multicolumn{2}{c}{ Crop } \\
\hline Group identifier & Starving & Feeding & Starving & Feeding \\
GAPDH & 0.010 & 0.121 & 0.000 & 0.060 \\
TUB & 0.014 & 0.156 & 0.002 & 0.010 \\
L26 & 0.413 & 0.428 & 0.143 & 0.064 \\
ACT & 0.019 & 0.084 & 0.000 & 0.333 \\
18S & 0.206 & 0.062 & 0.057 & 0.004 \\
\hline
\end{tabular}

Intra-group variation close to zero indicates high stability organisms, such as HPRT (hypoxanthine-guanine phosphoribosyltransferase), ubiquitin and TBP (TATA-box binding protein), but their sequences are not currently available in the $R$. prolixus databases.

The five candidate reference genes chosen were analyzed by three different statistical models because we assumed that a comparison of different algorithms enables a better evaluation of the most reliable reference genes and avoids the selection of co-regulated transcripts [37]. The sofwares geNorm, BestKeeper and NormFinder are the most common statistical algorithms used for reference gene validation, are easy to use and freely available for download. The geNorm software [13] is one of the most commonly used algorithms to compare the expression stability levels among different transcripts. The authors suggest that at least two reference genes should always be used to ensure accurate normalization and that each candidate reference gene should be validated before its use to ensure that it is stably expressed under the given experimental conditions. The geNorm analysis identified a pair of genes as the best reference genes for use in $R$. prolixus studies. In addition, the program can determine the optimal number of genes required for accurate normalization by calculating pair-wise variations. The major problem of the geNorm algorithm is its sensitivity to co-regulation, which tends to select those genes with the highest degree of similarity in their expression profiles [26].

The BestKeeper algorithm estimates the variability in the expression of the candidate reference genes by calculating the $\mathrm{C}_{\mathrm{T}}$ data variations and by performing a comparative analysis based on pairwise correlations of all of the candidate gene combinations. The gene expression variation was calculated for the five candidate genes, and the standard deviation (SD) provided an estimate of their stability.

NormFinder is another Excel-based visual basic application that assigns stability values to single candidate 
reference genes. Similar to geNorm, the NormFinder algorithm is based on expression values rather than the $\mathrm{C}_{\mathrm{T}}$, uses a model-based approach for the estimation of expression variation among the candidate genes and takes into account variations among and within subgroups. Low stability values indicate less variation in gene expression. It also avoids misinterpretations caused by the artificial selection of co-regulated genes. The advantage of NormFinder in comparison to the two other programs is its ability to analyze the candidate reference genes according to their intra- and inter-group expression variations.

The results obtained from the three programs used in this study indicated that the stability of all five of the tested reference genes were under the threshold value required for a transcript to be considered a reliable reference gene. The exceptions were the $L 26$ gene in the salivary glands in the blood feeding condition and $A C T$ in the crop of blood-fed insects, which were considered unacceptable by the BestKeeper and Normfinder analysis, respectively. Moreover, L26 and GAPDH were identified by the geNorm with M-values above 0.5 , which is the cut-off used by Hellemans et al. [38] to classify as stably expressed genes in relatively homogeneous samples. In nearly all of the conditions, the three programs classified L26 among the two least stable genes and GAPDH was the gene that showed more ranking variation among programs. Although their use as reference gene was considered acceptable, it should be used with caution because there are other more suitable reference genes. Previous works with triatomines [18] and mosquitoes [39] have shown that the expression of GAPDH has a transcription regulation profile in intestinal tissues after the bloodmeal.

The housekeeping gene data sets from the geNorm and BestKeeper analyses were similar, with slight differences in the first positions of the ranking order. Instead of $18 \mathrm{~S}$, which often appeared as one of the three most stable genes in the geNorm and BestKeeper analyses, the NormFinder algorithm identified GAPDH as one of the three most stable reference genes. The best combinations of two genes proposed by the geNorm and NormFinder algorithms were different. Variation among programs was previously observed $[40,41]$ and is mainly due to the different statistical algorithms used by each of them. GeNorm uses as most important criteria the expression ratio of the two genes evaluated while NormFinder is based in the least intra and inter group variations in gene expression and BestKeeper considers the stability (SD) and relationship to the BestKeeper index ( $\mathrm{r}$ and $\mathrm{p}$ values) calculated by the software.

Our results showed that $18 \mathrm{~S}$ demonstrated high expression stability for almost all of the samples analyzed by the geNorm and BestKeeper algorithms, and this finding enables its use as a housekeeping gene. $18 \mathrm{~S}$
rRNA was previously shown suitable to be used as reference gene in other $R$. prolixus organs such as the posterior midgut, and fat body [18]. However, the use of rRNA as an endogenous control for qPCR has been criticized because it does not always represent the mRNA fraction [42] and the high abundance of rRNA makes it difficult to accurately subtract the baseline value for the qPCR data analysis. Jiang et al. [43] reported the inappropriate use of the $18 \mathrm{~S}$ rRNA gene as a reference in studies with the insect Liposcelis bostrychophila. The rRNA constitutes the largest fraction of RNA in the cell (up to approximately $80 \%$ ), while the mRNA corresponds to approximately $5 \%$ of the total RNA. Thus, normalization errors can be caused by variations in cellular rRNA, which will change the total RNA content [44].

$T U B$ was also among the top of the rankings of the most stable genes in all of the conditions regardless of the program used. Consequently, it can be used as a reference gene for general use in qPCR normalization in hematophagy and triatomine- trypanosomatid interaction studies.

The results obtained in this work confirmed that $A C T$, one of the most widely used genes, is a suitable and reliable reference gene for triatomine studies to compare different treatments in the same organ. This gene displayed high stability in the salivary glands and the crop in almost all of the experimental conditions. However, in the crop of insects subjected to blood feeding, $A C T$ was the worst housekeeping gene with the lowest expression stability. This finding was observed in all three of the software programs and indicates that the use of $A C T$ as a reference gene should be avoided in this experimental condition. Moreover, Majerovicz et al. showed that $A C T$ expression levels vary considerably between tissues and it should not be used to compare different organs [18]. Similar results were reported in studies of cellular growth and differentiation [45]. During and after hematophagy of $R$. prolixus (as for other triatomines), the crop (the portion of the intestine that stores the ingested blood) volume significantly increases with the blood input to the digestive tract, and the abdominal cuticle needs to stretch to support the diet [46]. $\beta$-actin plays key roles in cell motility and cytoskeleton maintenance [47], and its expression in intestinal cells is probably affected by the morphological alterations caused by blood feeding.

\section{Conclusions}

In conclusion, this work defines the appropriateness of candidate genes for use as qPCR reference genes in the salivary glands and crop of $R$. prolixus studies. Our data showed that the expression stability of the genes varies in different tissue samples and under different 
experimental conditions. The results provided by three easily accessible statistical packages emphasize the suitability of all five of the tested reference genes in both the crop and the salivary glands with only a few exceptions. The gene (or combination of genes) to be used as a reference should be chosen depending on the experimental conditions. Under the conditions used here, the geNorm analysis suggested that the combined use of the two most stable genes is sufficient for an accurate normalization in all of the tissues and conditions analyzed.

\section{Additional material}

Additional file 1: Table of single $\mathrm{Ct}$ values of all candidate reference genes evaluated in this study in salivary glands and in the intestine in each experimental condition. Ct mean and standard deviation of $\mathrm{Ct}$ values of candidate reference genes.

\begin{abstract}
Abbreviations
CDNA: Complementary DNA; PCR: Polymerase chain reaction; qPCR: Quantitative real-time polymerase chain reaction; TUB: a-tubulin; Ct: Cycle threshold; ACT: $\beta$-actin; GADPH: Glyceraldehyde-3-phosphatedehydrogenase; SD: Standard deviation; UGALT: UDP-galactose translocator; Tm: Melting temperature
\end{abstract}

\section{Acknowledgements}

This work was supported by grants from the Conselho Nacional de Desenvolvimento Científico e Tecnológico (CNPq), the Coordenação de Aperfeiçoamento de Pessoal de Nível Superior (CAPES), the Fundação de Amparo à Pesquisa do Estado de Minas Gerais (FAPEMIG), and the INCTEntomologia Molecular and Pró-Reitoria de Pesquisa da UFMG.

\section{Author details}

'Departamento de Parasitologia, Instituto de Ciências Biológicas, Universidade Federal de Minas Gerais. Bloco 14, Sala 177, Av. Antonio Carlos 6627, Pampulha, CEP 30270-901 Belo Horizonte, MG, Brazil. ${ }^{2}$ Centro de Pesquisa René Rachou, Avenida Augusto de Lima, 1715, CEP 30190-002, Belo Horizonte, MG, Brazil. Instituto Nacional de Ciência e Tecnologia em Entomologia Molecular, Rio de Janeiro, Brazil.

\section{Authors' contributions}

RMP performed all the experimental procedures, data analysis, write the manuscript and was the primary author of the manuscript. MHP, NFG and AAG assisted in manuscript revising and provided helpful discussions. RDP performed salivary glands and intestine dissections and sample preparations. JOR maintained the trypanosomatids culture and infected the triatomines. RNA conceived and supervised the research. All authors read and approved the final manuscript.

\section{Competing interests}

The authors declare that they have no competing interests.

Received: 12 October 2011 Accepted: 6 March 2012

Published: 6 March 2012

\section{References}

1. Garcia ES, Genta F, Azambuja P, Schaub GA: Interaction between intestinal compounds of triatomines and Trypanosoma cruzi. Trends Parasitol 2010, 26:499-505.

2. Garcia ES, Mello CB, Azambuja P, Ribeiro JM: Rhodnius prolixus: salivary antihemostatic components decrease with Trypanosoma rangeli infection. Exp Parasitol 1994, 78:287-293.
3. Hecker H, Schwarzenbach M, Rudin W: Development and interactions of Trypanosoma rangel in and with the reduviid bug Rhodnius prolixus. Parasitol Res 1990, 76:311-318.

4. D'Alessandro-Bacigalupo A, Saraiva NG: Trypanosoma rangeli. In Parasitic protozoa. In Trypanosoma rangeli in Parasitic protozoa. Volume 2.. 2 edition. Edited by: Kreir JPB J. London: Academic; 1992:1-54.

5. Araujo RN, Soares AC, Paim RM, Gontijo NF, Gontijo AF, Lehane MJ, Pereira MH: The role of salivary nitrophorins in the ingestion of blood by the triatomine bug Rhodnius prolixus (Reduviidae: Triatominae). Insect Biochem Mol Biol 2009, 39:83-89.

6. Araujo RN, Campos IT, Tanaka AS, Santos A, Gontijo NF, Lehane MJ, Pereira MH: Brasiliensin: A novel intestinal thrombin inhibitor from Triatoma brasiliensis (Hemiptera: Reduviidae) with an important role in blood intake. Int J Parasitol 2007, 37:1351-1358.

7. Ribeiro JM, Schneider M, Isaias T, Jurberg J, Galvao C, Guimaraes JA: Role of salivary antihemostatic components in blood feeding by triatomine bugs (Heteroptera). J Med Entomol 1998, 35:599-610.

8. Garcia ES, Ratcliffe NA, Whitten MM, Gonzalez MS, Azambuja P: Exploring the role of insect host factors in the dynamics of Trypanosoma cruziRhodnius prolixus interactions. J Insect Physiol 2007, 53:11-21.

9. Megy K, Hammond M, Lawson D, Bruggner RV, Birney E, Collins FH: Genomic resources for invertebrate vectors of human pathogens, and the role of VectorBase. Infect Genet Evol 2009, 9:308-313.

10. Schofield CJ: Triatominae: Biología y control. 1 edition. UK: Eurocomunica Publications; 1994

11. Ribeiro JM, Andersen J, Silva-Neto MA, Pham VM, Garfield MK, Valenzuela JG: Exploring the sialome of the blood-sucking bug Rhodnius prolixus. Insect Biochem Mol Biol 2004, 34:61-79.

12. Medeiros MN, Logullo R, Ramos IB, Sorgine MH, Paiva-Silva GO, Mesquita RD, Machado EA, Coutinho MA, Masuda H, Capurro ML, et al: Transcriptome and gene expression profile of ovarian follicle tissue of the triatomine bug Rhodnius prolixus. Insect Biochem Mol Biol 2011, 41:823-831.

13. Vandesompele J, De Preter K, Pattyn F, Poppe B, Van Roy N, De Paepe A, Speleman F: Accurate normalization of real-time quantitative RT-PCR data by geometric averaging of multiple internal control genes. Genome Biol 2002, 3:1-11.

14. Radonic A, Thulke S, Mackay IM, Landt O, Siegert W, Nitsche A: Guideline to reference gene selection for quantitative real-time PCR. Biochem Biophys Res Commun 2004, 313:856-862.

15. Shen $G M$, Jiang HB, Wang $X N$, Wang JJ: Evaluation of endogenous references for gene expression profiling in different tissues of the oriental fruit fly Bactrocera dorsali (Diptera: Tephritidae). BMC Mol Biol 2010, 11:76.

16. Hornakova D, Matouskova P, Kindl J, Valterova I, Pichova I: Selection of reference genes for real-time polymerase chain reaction analysis in tissues from Bombus terrestris and Bombus lucorum of different ages. Anal Biochem 2010, 397:118-120.

17. Scharlaken B, de Graaf DC, Goossens K, Brunain M, Peelman LJ, Jacobs FJ: Reference gene selection for insect expression studies using quantitative real-time PCR: The head of the honeybee, Apis mellifera, after a bacterial challenge. J Insect Sci 2008, 8:1-10.

18. Majerowicz D, Alves-Bezerra M, Logullo R, Fonseca-de-Souza AL, MeyerFernandes JR, Braz GR, Gondim KC: Looking for reference genes for realtime quantitative PCR experiments in Rhodnius prolixus (Hemiptera: Reduviidae). Insect Mol Biol 2011, 20:713-722.

19. Sanger $F$, Nicklen $S$, Coulson AR: DNA sequencing with chain-terminating inhibitors. Proc Natl Acad Sci USA 1977, 74:5463-5467.

20. Ewing B, Hillier L, Wendl MC, Green P: Base-calling of automated sequencer traces using phred. I Accuracy assessment. Genome Res 1998, 8:175-185.

21. Ewing B, Green P: Base-calling of automated sequencer traces using phred. II. Error probabilities. Genome Res 1998, 8:186-194.

22. Gordon D, Abajian C, Green P: Consed: a graphical tool for sequence finishing. Genome Res 1998, 8:195-202.

23. Altschul SF, Gish W, Miller W, Myers EW, Lipman DJ: Basic local alignment search tool. J Mol Biol 1990, 215:403-410.

24. Pfaffl MW: A new mathematical model for relative quantification in realtime RT-PCR. Nucleic Acids Res 2001, 29:e45.

25. Condori J, Nopo-Olazabal C, Medrano G, Medina-Bolivar F: Selection of reference genes for qPCR in hairy root cultures of peanut. BMC Res Notes 2011, 4:392. 
26. Andersen $C L$, Jensen $J$, Orntoft TF: Normalization of real-time quantitative reverse transcription-PCR data: a model-based variance estimation approach to identify genes suited for normalization, applied to bladder and colon cancer data sets. Cancer Res 2004, 64:5245-5250.

27. Pfaffl MW, Tichopad A, Prgomet C, Neuvians TP: Determination of stable housekeeping genes, differentially regulated target genes and sample integrity: BestKeeper-Excel-based tool using pair-wise correlations. Biotechnol Lett 2004, 26:509-515.

28. Bustin SA: Quantification of mRNA using real-time reverse transcription PCR (RT-PCR): trends and problems. J Mol Endocrinol 2002, 29:23-39.

29. de Marco R, Lovato DV, Torquato RJ, Clara RO, Buarque DS, Tanaka AS: The first pacifastin elastase inhibitor characterized from a blood sucking animal. Peptides 2010, 31:1280-1286.

30. Paim RM, Araujo RN, Soares AC, Lemos LC, Tanaka AS, Gontijo NF, Lehane MJ, Pereira MH: Influence of the intestinal anticoagulant in the feeding performance of triatomine bugs (Hemiptera; Reduviidae). Int J Parasitol 2011, 41:765-773.

31. Paluzzi JP, Orchard I: A second gene encodes the anti-diuretic hormone in the insect,Rhodnius prolixus. Mol Cell Endocrinol 2010, 317:53-63.

32. Alves-Bezerra M, Majerowicz D, Grillo LA, Tremonte $H$, Almeida CB, Braz GR, Sola-Penna M, Paiva-Silva GO, Gondim KC: Serotonin regulates an acylCoA-binding protein (ACBP) gene expression in the midgut of Rhodnius prolixus. Insect Biochem Mol Biol 2010, 40:119-125.

33. Ramos IB, Campos CB, Sorgine MH, de Souza W, Machado EA: Calreticulin expression levels and endoplasmic reticulum during late oogenesis and early embryogenesis of Rhodnius prolixu Stahl. Mol Biol Rep 2010, 38:1757-1767.

34. Ursic-Bedoya RJ, Lowenberger CA: Rhodnius prolixus: identification of immune-related genes up-regulated in response to pathogens and parasites using suppressive subtractive hybridization. Dev Comp Immunol 2007, 31:109-120.

35. Ursic-Bedoya RJ, Nazzari H, Cooper D, Triana O, Wolff M, Lowenberger C: Identification and characterization of two novel lysozymes from Rhodnius prolixus, a vector of Chagas disease. J Insect Physiol 2008, 54:593-603.

36. Araujo RN, Santos A, Pinto FS, Gontijo NF, Lehane MJ, Pereira MH: RNA interference of the salivary gland nitrophorin 2 in the triatomine bug Rhodnius prolixus (Hemiptera: Reduviidae) by dsRNA ingestion or injection. Insect Biochem Mol Biol 2006, 36:683-693.

37. Tong Z, Gao Z, Wang F, Zhou J, Zhang Z: Selection of reliable reference genes for gene expression studies in peach using real-time PCR. BMC Mol Biol 2009, 10:71.

38. Hellemans J, Mortier G, De Paepe A, Speleman F, Vandesompele J: qBase relative quantification framework and software for management and automated analysis of real-time quantitative PCR data. Genome Biol 2007 $8: R 19$

39. Sanders HR, Evans AM, Ross LS, Gill SS: Blood meal induces global changes in midgut gene expression in the disease vector, Aedes aegypti. Insect Biochem Mol Biol 2003, 33:1105-1122.

40. Mehta R, Birerdinc A, Hossain N, Afendy A, Chandhoke V, Younossi Z, Baranova A: Validation of endogenous reference genes for QRT-PCR analysis of human visceral adipose samples. BMC Mol Biol 2010, 11:39.

41. Sorby LA, Andersen SN, Bukholm IR, Jacobsen MB: Evaluation of suitable reference genes for normalization of real-time reverse transcription PCR analysis in colon cancer. J Exp Clin Cancer Res 2010, 29:144.

42. Solanas M, Moral R, Escrich E: Unsuitability of using ribosomal RNA as loading control for Northern blot analyses related to the imbalance between messenger and ribosomal RNA content in rat mammary tumors. Anal Biochem 2001, 288:99-102.

43. Jiang HB, Liu YH, Tang PA, Zhou AW, Wang JJ: Validation of endogenous reference genes for insecticide-induced and developmental expression profiling of Liposcelis bostsrychophila (Psocoptera: Liposcelididae). Mol Biol Rep 2010, 37:1019-1029.

44. Hansen MC, Nielsen AK, Molin S, Hammer K, Kilstrup M: Changes in rRNA levels during stress invalidates results from mRNA blotting: fluorescence in situ rRNA hybridization permits renormalization for estimation of cellular mRNA levels. J Bacteriol 2001, 183:4747-4751.

45. Ruan W, Lai M: Actin, a reliable marker of internal control? Clin Chim Acta 2007, 385:1-5
46. Guarneri AA, Diotaiuti L, Gontijo NF, Gontijo AF, Pereira MH: Blood-feeding performance of nymphs and adults of Triatoma brasiliensis on human hosts. Acta Trop 2003, 87:361-370.

47. Hunter T, Garrels Jl: Characterization of the mRNAs for alpha-, beta- and gamma-actin. Cell 1977, 12:767-781.

doi:10.1186/1756-0500-5-128

Cite this article as: Paim et al:: Validation of reference genes for expression analysis in the salivary gland and the intestine of Rhodnius prolixus (Hemiptera, Reduviidae) under different experimental conditions by quantitative real-time PCR. BMC Research Notes 2012 5:128.

\section{Submit your next manuscript to BioMed Central and take full advantage of:}

- Convenient online submission

- Thorough peer review

- No space constraints or color figure charges

- Immediate publication on acceptance

- Inclusion in PubMed, CAS, Scopus and Google Scholar

- Research which is freely available for redistribution

Submit your manuscript at www.biomedcentral.com/submit
C Biomed Central 